\title{
SPRAWOZDANIA
}

\section{LUBELSKIE SYMPOZJUM NAUKOWE RZYMSKIEGO PRAWA KARNEGO, „PRAWO KaRNE I POLITYKA W PAŃSTWIE RZYMSKIM”, LUBLIN, 16-17 MAJA 2014 R.}

Niemal tradycją wśród polskich romanistów są organizowane od wielu już lat przez Katedrę Prawa Rzymskiego UMCS lubelskie sympozja poświęcone rzymskiemu prawu karnemu. Pomysłodawcą tych spotkań był prof. Marek Kuryłowicz, który przez kolejne lata dbał o podtrzymanie tejże tradycji. Regularnie, niemal co dwa lata „zwoływał" więc wszystkich miłośników prawa rzymskiego do Lublina na kilkudniowe obrady. Ostatnie, ósme już Sympozjum odbyło się w dniach 16-17 maja 2014 roku, a jego tematem przewodnim było Prawo karne i polityka w prawie rzymskim. Tym razem jednak romaniści z całej Polski ściągnęli do Lublina nie tylko z chęci przedyskutowania wyników swoich najnowszych badań, ale przede wszystkim po to, by uczcić i wraz z organizatorami spotkania, Katedrą Prawa Rzymskiego UMCS oraz Zakładem Historii Starożytnej UMCS, uhonorować prof. Marka Kuryłowicza z okazji jego Jubileuszu 70-lecia urodzin.

Podobnie jak wyjątkowa była przyczyna spotkania, tak i wyjątkowe było jego miejsce. Goście zebrali się bowiem w jednej z sal pałacu Czartoryskich będącego siedzibą Lubelskiego Towarzystwa Naukowego. Sympozjum zainaugurowała Dziekan WPiA UMCS, prof. dr hab. Anna Przyborowska-Klimczak. Następnie głos zabrali Rektor UMCS, prof. UMCS dr hab. Stanisław Michałowski, Rektor KUL, ks. prof. dr hab. Antoni Dębiński, prof. dr hab. Kazimierz Goebel a także wiceprezes Lubelskiego Towarzystwa Naukowego, prof. Artur Korobowicz. Wszyscy gratulowali Jubilatowi imponującego dorobku naukowego i życzyli kolejnych sukcesów. Nie zabrakło również wspomnień czy zabawnych anegdot $\mathrm{z}$ udziałem prof. M. Kuryłowicza. Nierzadko 
prelegenci wracali pamięcią do czasów studenckich opisując swoje pierwsze z nim spotkania. Najwięcej uśmiechu, również na twarzy samego Jubilata, wywołało wystąpienie prof. Krzysztofa Amielańczyka (UMCS). Przedstawił on bowiem prof. M. Kuryłowicza jako osobę o trzech „rzymskich obliczach”: władnego imperatora, troskliwego pater familias oraz ,głowę sekty rzymskiego prawa karnego”. Na koniec każdy z zebranych miał możliwość osobiście złożyć życzenia Jubilatowi.

Po obiedzie rozpoczęła się, tym razem już w budynku Wydziału Prawa i Administracji UMCS, pierwsza sesja obrad. Otworzył ją prof. M. Kuryłowicz, a pierwszym prelegentem był prof. Jan Zabłocki (UKSW), który wygłosił referat zatytułowany 'Iudicis et amici officium salvare’. Na marginesie Gell. 1.3. Dalsza część sesji odbywała się pod przewodnictwem prof. K. Amielańczyka. Referaty zaś wygłosili: prof. Anna Pikulska-Radomska (UŁ) - „... A kiedy pieniędzy publicznych na to nie wystarczało...". Uwagi o karaniu lichwiarstwa $w$ rzymskiej republice, prof. Marzena Dyjakowska (KUL) - Aulus Gellius, Noctes Atticae 4,14, czyli o prawnokarnych granicach ochrony godności urzędniczej oraz dr hab. Renata Świrgoń-Skok (UR) - Polityczne aspekty ustaw karnych cesarza Justyniana $w$ sprawach religijnych.

Po przerwie na kawę wznowiono obrady, a przewodniczyła im prof. Maria Zabłocka (UW). Jako pierwszy z referatem poświęconym Represjom karnym stosowanym wobec bankierów rzymskich ('nummularii') wystąpił prof. Piotr Niczyporuk (UwB). Po nim głos zabrał prof. Wiesław Mossakowski (UMK), który wygłosił referat o Zakreśleniu odpowiedzialności karnej w 'inscriptio’ w procesie karnym późnego cesarstwa. Ostatnie wystąpienie tego dnia należało do prof. K. Amielańczyka, a dotyczyło Prawa karnego i polityki. Czy rzymscy prawodawcy prowadzili ukierunkowana politykę karną?

Po wysłuchaniu wszystkich referatów nawiązała się dyskusja. Udział w niej wzięli: prof. Anna Tarwacka (UKSW), dr hab. Maciej Jońca (KUL), dr hab. Jacek Wiewiorowski (UAM), dr hab. Dariusz Słapek (UMCS), dr Henryk Kowalski (UMCS), dr Dorota Stolarek (KUL), prof. Janusz Sondel oraz prof. Andrzej Sokala (UMK). 
Pierwszy dzień Sympozjum zakończył się uroczystą kolacją. Była ona doskonałą okazją do tego, by raz jeszcze pogratulować Jubilatowi jego długoletniej, znakomitej pracy naukowej i dydaktycznej, a także życzyć mu kolejnych sukcesów w życiu zawodowym oraz prywatnym.

Drugiego dnia Konferencji obrady otworzył referat prof. Bronisława Sitka (UWM) na temat Pozycji prawnej 'advocatus fisci'. Kolejne wystąpienia należały do prof. Anny Tarwackiej (UKSW) - Jak sie zemścić na cenzorach? Zakres odpowiedzialności karnej strażników moralności, dr hab. Dariusza Słapka (UMCS) - 'Instrumentum vocale' czyli o niezwyktych negocjacjach władz rzymskich z... niewolnikami Antoniusza, dr hab. Jacka Wiewiorowskiego (UAM) - CTh 9.14.1 = C. 9.16 .7 (a. 374) - pierwszy dziejowy zakaz dzieciobójstwa?, dr hab. Macieja Jońcy - 'Telum manu fugit'. Uwagi na temat nieumyślności w Dekrecie Gracjana, dr hab. Henryka Kowalskiego - Polityka a prawo karne. Ustawodawstwo karne cesarza Augusta na tle wydarzeń w latach 22-18 p.n.e., dr Anny Pawłowskiej - Sposoby wykonania kary śmierci: polityka czy ,fantazja” cesarska ? oraz dr Andrzeja Chmiela - Proces katylinarczyków jako przykład rzymskiego , procesu politycznego”. Po ożywionej dyskusji, którą wywołały referaty, przewodniczący zamknął ósme Sympozjum naukowe rzymskiego prawa karnego.

Renata Kamińska*

Seminario Eurasiatico di DiritTo ROMANo, «REPUBbliCA E DIFESA DEI DIRITTI DELL'UOMO E DEL CITTADINO. RECEZIONE E INSEGNAMENTO DEL DIRITTO ROMANO», Stambut, 30-31 maja 2014 R.

W dniach 30-31 maja 2014 r. w Stambule odbyło się drugie Seminario Eurasiatico di diritto romano (Euroazjatyckie seminarium prawa rzymskiego), pod hasłem: «Repubblica e difesa dei diritti dell'uomo e

* Uniwersytet Kardynała Stefana Wyszyńskiego 